\title{
Marcas avaliativas em imagens jornalísticas
}

\author{
Appraisal marks in newspaper images
}

Marcas de evaluación en imágenes periodísticas

\author{
Cristiane Salete Florek ${ }^{1}$
}

\begin{abstract}
RESUMO: Cotidianamente, avaliamos e temos nossos pensamentos, sentimentos, opiniões e atitudes avaliados. Em termos teóricos, o Sistema de Avaliatividade (MARTIN; WHITE, 2005) nos possibilita investigar os recursos usados para a atribuir valor à nossa experiência social. Objetivando investigar a avaliatividade em imagens, analisamos cinco imagens jornalísticas quanto: i) ao contexto de publicação e de recontextualização; ii) à estrutura multifuncional; e iii) aos itens avaliativos. Os resultados demonstram: i) a prevalência das marcas avaliativas atitudinais de afeto; ii) presença de julgamento explícito (ideacionalmente representado) ou implícito (atribuído pelo leitor); iii) apreciação implícita e atribuída pelo leitor; iv) engajamento por expansão dialógica, realizado pelo enquadramento da foto; v) gradação como ponto de entrada para a avaliação visual. Esses resultados demonstram a importância de sistematizar categorias de análise e de considerar a avaliatividade como importante fonte de informação no estudo de textos multimodais, especialmente os que englobam linguagem visual estática.
\end{abstract}

PALAVRAS-ChAVE: Sistema de Avaliatividade. Imagens jornalísticas. Multimodalidade.

ABSTRACT: Everyday we evaluate and we have our thoughts, feelings, opinions and attitudes evaluated. In theoretical terms, Appraisal (MARTIN; WHITE, 2005) enables us to investigate the resources used to attribute value to our social experience. Aiming to investigate Appraisal in images, we analyzed five journalistic images regarding: i) the context of publication and recontextualization; ii) the multifunctional structure; and iii) the evaluative lexical items. The results show: i) prevalence of attitudinal evaluative marks of affection; ii) the presence of explicit judgment (ideacionalmente shown) or implicit judgment (assigned by the reader); iii) implicit assessment and assigned assesment afforded by the reader; iv) engagement by dialogic expansion carried out by the photo frame; v) gradient as the entry point for visual evaluation. These results demonstrate the importance of systematizing categories of analysis and of considering

\footnotetext{
1 Possui graduação em Letras pela Universidade Federal de Pelotas (2008) e mestrado em Letras pela Universidade Federal de Santa Maria (2015). Atualmente, é bolsista de doutorado da Universidade Federal de Santa Maria. Tem experiência na área de Linguística, com ênfase em Linguística Aplicada, atuando principalmente nos seguintes temas: Análise Crítica de Gênero, Análise do Discurso Multimodal, Multiletramentos.
} 
appraisal as an important information source in the study of the meanings from multimodal texts, especially those involving static visual language.

Key Words: Appraisal. Journalistic images. Multimodality.

RESUMEN: Cotidianamente, evaluamos y tenemos nuestros pensamientos, sentimientos, opiniones y actitudes evaluadas. En términos teóricos, el Sistema de Evaluación (MARTIN, WHITE, 2005) nos permite investigar los recursos utilizados para atribuir valor a nuestra experiencia social. Con el objetivo de investigar la evaluatividad en imágenes, analizamos cinco imágenes periodísticas en consideración a: i) el contexto de publicación y de recontextualización; ii) la estructura multifuncional; y iii) los elementos de evaluación. Los resultados demuestran: i) la prevalencia de las marcas evaluadoras actitudinales de afecto; ii) presencia de juicio explícito (idealmente representado) o implícito (atribuido por el lector); ii) apreciación implícita y atribuida por el lector; iv) compromiso por expansión dialógica, realizado por el encuadramiento de la foto; v) gradación como punto de entrada para la evaluación visual. Estos resultados demuestran la importancia de sistematizar categorías de análisis y de considerar la evaluación como importante fuente de información en el estudio de textos multimodales, especialmente los que engloban lenguaje visual estático.

Palabras clave: Sistema de Evaluación. Imágenes periodísticas. Multimodalidad.

\section{Introdução}

Contemporaneamente, os avanços da tecnologia vêm provocando mudanças nos mais variados contextos e práticas sociais e, por consequência, nas formas de materialização da linguagem (COPE; KALANTZIS, 2000; KRESS; VAN LEEUWEN, 2001; LANKSHEAR; KNOBEL, 2003; KRESS, 2003, p. ex.). Especialmente no campo da Linguística Aplicada, cada vez mais as implicações sociais do rápido aumento em sofisticação e variedade de práticas linguísticas que congregam vários modos semióticos (verbal - escrito e oral; visual estático e em movimento; sonoro, p. ex.) estão sendo investigadas (p. ex., imagens: O'TOOLE, 1994; KRESS; VAN LEEUWEN, 2006; música, som e fala: VAN LEEUWEN, 1999; cor: KRESS; VAN LEEUWEN, 2002; e combinações de diferentes modos semióticos: ROYCE, 1998; 2002; 2007; 2015; MARTINEC; SALWAY, 2005; BATEMAN, 2008; MARTINEC, 2013), visando sistematizar, analisar e teorizar sobre como os diferentes modos semióticos se configuram isoladamente e consorciados a outros modos semióticos para produzir sentido. 
De modo geral, esses estudos têm como pano de fundo a perspectiva sociossemiótica instaurada pela Linguística Sistêmico-Funcional (HALLIDAY; HASAN, 1985; HALLIDAY, 1994; HALLIDAY; MATTHIESSEN, 2004; 2014). Essa perspectiva expande o tradicional conceito de semiótica como estudo dos signos (SAUSSURE, 1975, p. ex.) para uma concepção de semiótica como estudo dos sistemas de signos que são selecionados pelos participantes da comunicação para a produção de sentido no âmbito do sistema social (HALLIDAY; MATTHIESSEN, 2004). Além disso, a perspectiva sistêmicofuncional propõe que a linguagem realiza, simultaneamente, três funções: ideacional; interpessoal e textual. A função ideacional expressa significados relativos à representação dos participantes, processos e circunstâncias envolvidos na atividade discursiva, a função interpessoal concretiza significados sobre as relações entre os envolvidos na atividade discursiva e a função textual revela o papel da linguagem na organização das informações ideacionais e interpessoais (HALLIDAY; MATTHIESSEN, 2004). Essas três metafunções, segundo Halliday e Matthiessen (2004), ocorrem simultaneamente, perpassando diferentes níveis ou estratos de realização: fonologia e grafologia, léxico-gramática, semântica, contexto de situação e contexto de cultura.

Martin (2001, p. 311), no entanto, afirma que, embora existam estudos consistentes sobre a realização dos significados ideacionais (p. ex., LEMKE, 1998; O'HALLORAN, 1999) e dos significados textuais (p. ex. KRESS; VAN LEEUWEN, 1998) em diferentes modos semióticos, a metafunção interpessoal carece de estudos mais aprofundados. Martin e White (2005), por exemplo, detalharam a metafunção interpessoal e propuseram o Sistema de Avaliatividade para o modo semiótico verbal. Contudo, até o momento, estudos como o de Economou (2009), sobre a avaliatividade em outros modos semióticos, são pouco numerosos.

Com base na perspectiva sociossemiótica e multifuncional da linguagem, o modo semiótico visual, especialmente as imagens estáticas, são entendidas e estudadas como "textos visuais, que se organizam segundo alguns princípios e 
regularidades, conforme os usos que fazemos delas em diferentes situações" (HENDGES; NASCIMENTO; MARQUES, 2013， p. 241). Nesse sentido, acreditamos ser possível propor um sistema de avaliatividade (ainda que parcial) para imagens, com base na proposta de Martin e White (2005) para o modo semiótico verbal escrito e de Economou (2009) para a avaliatividade no modo semiótico visual estático. Para tanto, objetivamos analisar imagens do campo de conhecimento jornalístico, identificando, sistematizando e analisando os traços avaliativos que permeiam tais imagens. Pretendemos, a partir disso, propor categorias gerais para os itens avaliativos presentes no modo semiótico visual.

\section{Fundamentação Teórica}

Este estudo segue os pressupostos teórico-metodológicos do Sistema de Avaliatividade (MARTIN; WHITE, 2005) e da Gramática do Design Visual (KRESS; VAN LEEUWEN, 2006), duas teorias cujas categorias de análise derivam da sistematização da proposta teórico-metodológica de Halliday e Matthiessen $(2004,2014)$, a qual estuda a linguagem como um modo semiótico sistemático e multifuncional que produz sentido por meio da ativação simultânea de vários estratos linguísticos.

\section{Lendo Imagens: Gramática do Design Visual}

O construto teórico-metodológico da Gramática do Design Visual (KRESS; VAN LEEUWEN, 1990, 1996, 2006) propõe que as estruturas visuais se assemelham às estruturas linguísticas, possibilitando analisar uma imagem a partir de três metafunções simultâneas: representacional, interativa e composicional. Tais metafunções expressam, respectivamente: i) interpretações particulares da experiência; ii) constituem-se como formas de interação social; e iii) organizam as informações representadas e os valores interativos em uma unidade significativa, conforme as concepções compartilhadas consensualmente por um grupo. 
A metafunção representacional é realizada por estruturas narrativas ou conceituais. Os elementos ou categorias que possibilitam a representação da realidade por meio do modo semiótico visual, de acordo com Kress e van Leeuwen (2006), são participantes, processos (eventos) e circunstâncias.

Quanto aos participantes, existem dois tipos envolvidos nas representações visuais: i) participantes interativos; e ii) participantes representados. Os participantes interativos são aqueles envolvidos no ato comunicativo, são os produtores e os leitores da imagem. Os participantes representados são o assunto da comunicação, podem ser pessoas, coisas (reais ou abstratas) ou lugares representados na imagem.

Quanto aos processos, existem dois tipos de processos: i) narrativos; e ii) conceituais. Os processos narrativos são caracterizados pela presença de um vetor que conecta os participantes representados, apresentando-os "fazendo alguma coisa uns para os outros"2 (KRESS; VAN LEEUWEN, 2006, p. 59). Os vetores (formados por corpos, braços, pernas, ferramentas em ação, flechas, setas, p. ex.) são padrões de recorrência que caracterizam processos, eventos e ações que se desdobram ao longo do tempo. Os vetores em um processo narrativo podem variar em tipo e os participantes em número, possibilitando, assim, distinguir diferentes tipos de processos narrativos (KRESS; VAN LEEUWEN, 2006, p. 63). Existem seis tipos de processos narrativos: i) de ação; ii) de reação; iii) mentais; iv) verbais; v) de conversão; e vi) de simbolismo geométrico (Quadro 1).

\footnotetext{
${ }^{2}$ As traduções e adaptações de textos (verbais e visuais) em outras línguas e, quando for 0 caso, em português, são de responsabilidade da autora.
} 


\section{Quadro 1 - Processos Narrativos}

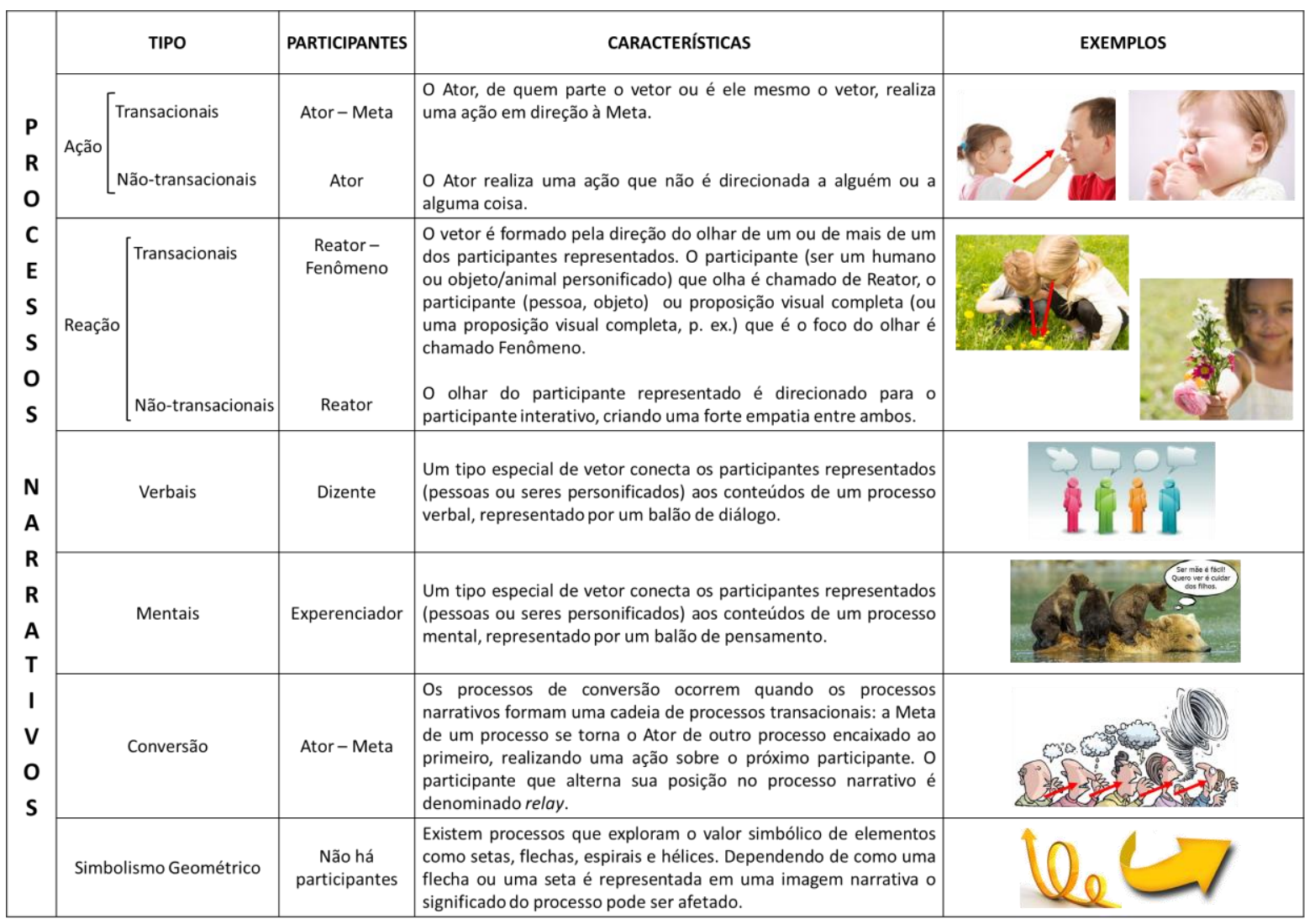

Fonte: Elaborado pela autora

Imagens narrativas podem conter participantes ditos secundários, participantes que mantém relação com o(s) participantes(s) principal(is), mas não por meio de vetores. Esses participantes são chamados de circunstâncias por Kress e van Leeuwen (2006, p. 72). Existem três tipos de circunstâncias: i) circunstâncias de lugar: conectam outros participantes a um participante que pode ser chamado de cenário; ii) circunstâncias de meio: são as ferramentas que são usadas para realizar a ação; e iii) circunstâncias de acompanhamento: apresentam os participantes distintamente, um em companhia do outro, um com o outro.

Os processos conceituais "representam os participantes em termos de sua essência mais generalizada, mais ou menos estável e menos temporal, em termos de classe, estrutura ou significado" (KRESS; VAN LEEUWEN, 2006, p. 
79). Esses processos podem ser de três tipos: i) classificacionais; ii) analíticos; e iii) simbólicos (Quadro 2).

\section{Quadro 2 - Processos Conceituais}

\begin{tabular}{|c|c|c|c|c|}
\hline$P$ & TIPO & PARTICIPANTES & CARACTERÍSTICAS & EXEMPLOS \\
\hline $\begin{array}{l}\text { R } \\
\text { O } \\
\text { C } \\
\text { E } \\
\text { S } \\
\text { S } \\
\text { O } \\
\text { S }\end{array}$ & Classificacionais & $\begin{array}{c}\text { Superordenado } \\
- \\
\text { Subordinado }\end{array}$ & $\begin{array}{l}\text { Os participantes da imagem são classificados em uma relação } \\
\text { taxonômica (tipo de), são representados em uma relação de } \\
\text { Superordenado(s) - Subordinados(s). Nessas imagens, os } \\
\text { processos são sempre visuais e os participantes podem ser } \\
\text { tanto visuais quanto verbais, ou ambos. Os participantes são } \\
\text { mostrados de uma forma objetiva, geralmente simétrica e, } \\
\text { principalmente, são julgados como membros de um grupo } \\
\text { particular. }\end{array}$ & \\
\hline $\begin{array}{l}\mathrm{C} \\
\mathrm{O} \\
\mathrm{N} \\
\mathrm{C}\end{array}$ & Analíticos & $\begin{array}{c}\text { Portador } \\
- \\
\text { Atributos } \\
\text { Possessivos }\end{array}$ & $\begin{array}{l}\text { Os participantes de um processo são representados a partir de } \\
\text { uma relação metonímica (parte-todo). Os participantes } \\
\text { representados que representam o todo são chamados Portador } \\
\text { e aqueles que representam as partes são os Atributos } \\
\text { Possessivos. }\end{array}$ & s) \\
\hline $\begin{array}{l}\mathrm{E} \\
\mathrm{I} \\
\mathrm{T} \\
\mathrm{U} \\
\mathrm{A} \\
\mathrm{I} \\
\mathrm{S}\end{array}$ & Simbólicos & $\begin{array}{c}\text { Portador } \\
- \\
\text { Atributos }\end{array}$ & $\begin{array}{l}\text { São processos que se referem ao significado atribuído a um } \\
\text { participante representado. Nesses processos, há um Portador e } \\
\text { outro participante que representa o próprio significado ou } \\
\text { identidade do Portador. } \\
\text { Nesses processos, o Portador já possui um significado } \\
\text { intrínseco, previamente conhecido pelo expectador da imagem } \\
\text { e, portanto, o Portador temo caráter de signo. }\end{array}$ & \\
\hline
\end{tabular}

Fonte: Elaborado pela autora

A metafunção interativa, segundo Hendges, Nascimento e Marques (2013, p. 244), como o próprio nome indica, trata dos significados interativos da imagem, isto é, "do potencial da imagem para produzir a sensação de que podemos interagir com o que está representado". A metafunção interativa possui "recursos de representação de interações e relações conceituais entre pessoas, lugares e coisas representadas em imagens" (KRESS; VAN LEEUWEN, 2006, p. 114) e, além disso, possui potencial para a criação e a manutenção das interações entre o produtor e o expectador da imagem. Essa metafunção, portanto, refere-se às funções interativas que o modo semiótico visual pode realizar, àquilo que "podemos fazer uns aos outros, ou uns pelos outros, por meio da comunicação visual e as relações entre os produtores e os expectadores implicados nos textos visuais" (KRESS; VAN LEEUWEN, 2006, p. 15). 
Segundo Kress e van Leeuwen (2006), os sistemas que possibilitam realizar as interações entre os participantes de uma imagem são: i) contato; ii) distância social; e iii) atitude. O contato é estabelecido imaginariamente com o expectador da imagem por meio do olhar e pode acontecer como: i) demanda: "o olhar do participante (e o gesto, se presente) solicita alguma coisa do expectador, solicita que o expectador estabeleça algum tipo de relação imaginária com ele ou ela" (como, neste artigo, na imagem que exemplifica os processos narrativos de reação não-transacional) (KRESS; VAN LEEUWEN, 2006, p. 118); ou ii) oferta: a imagem '"oferece' os participantes representados ao expectador como itens de informação, objetos de contemplação, impessoalmente, como se fossem amostras de uma vitrine" (como ocorre nas imagens que, neste artigo, exemplificam os processos narrativos de ação transacional e não-transacional e de reação transacional) (KRESS; VAN LEEUWEN, 2006, p. 119).

O sistema de distância social, de acordo com Kress e van Leeuwen (2006), é realizado pelo tamanho do enquadramento, que pode ser: i) íntimo (close-up); ii) médio; ou iii) distante. O sistema de atitude é realizado pela perspectiva - seleção de um ângulo, de um ponto de vista -, que possibilita expressar atitudes mais ou menos subjetivas em relação aos participantes representados, humanos ou outros (KRESS; VAN LEEUWEN, 2006, p. 129).

Conforme Kress e van Leeuwen (2006), a subjetividade pode indicar envolvimento ou distanciamento entre os participantes representados e os participantes interativos, bem como as relações de poder entre esses participantes. O nível de envolvimento da relação entre o produtor da imagem, o participante interativo e o participante representado é dado pelo ângulo horizontal, que pode ser: i) frontal; ou ii) oblíquo. $O$ ângulo frontal apresenta envolvimento elevado, pois facilita a identificação do participante interativo com os participantes representados. É frequentemente empregado quando os participantes representados exibem características consideradas positivas e que o produtor da imagem quer dar a ver ao participante interativo. O ângulo 
oblíquo, em contrapartida, revela o distanciamento do produtor da imagem com aquilo que apresenta, o plano da imagem e o plano do produtor da imagem não são coincidentes.

As escolhas relativas ao ângulo vertical, estabelecido entre participante representado e participante interativo (produtor e expectador da imagem), codificam visualmente a sua relação de poder (KRESS; VAN LEEUWEN, 2006). O ângulo vertical pode ser: i) alto; ii) ao nível dos olhos; ou iii) baixo. Se um participante representado é visto a partir de um ângulo alto em relação ao participante interativo, então a relação entre os participantes interativos e os participantes representados é mostrada como uma relação na qual produtor e expectador têm poder sobre aquilo ou aquele que é representado - "o participante representado é visto da perspectiva do poder" (KRESS; VAN LEEUWEN, 2006, p. 140). Se a escolha for de um ângulo baixo, os elementos representados exercem poder sobre os espectadores. Se a escolha for representar uma relação de igualdade, então, os participantes representados estarão ao nível do olhar dos participantes interativos.

Imagens objetivas, conforme Kress e van Leeuwen (2006), são realizadas de duas maneiras: i) por um ângulo frontal; ou ii) por um ângulo perpendicular de cima para baixo. Imagens da ciência e imagens técnicas, normalmente, codificam atitudes objetivas.

A interação em imagens, segundo Kress e van Leeuwen (2006), também pode ocorrer por meio da modalidade, marcadores visuais que possibilitam interpretar uma imagem como mais ou menos naturalistica ou visível. Segundo Hendges, Nascimento e Marques (2013, p. 253), "algumas características visuais nos permitem detectar o grau de veracidade atribuído a uma representação e avaliar sua legitimidade de acordo com os objetivos em diferentes gêneros e com as condutas reconhecidas em determinadas esferas sociais". A concepção de natural ou visíve/ varia de contexto para contexto. Kress e van Leeuwen (2006, p. 165) adotam o termo de Bernstein (1988) orientação do código para demonstrar como os princípios de realidade variam 
de acordo com o contexto (tecnológico, sensorial, abstrato e naturalístico) em que a imagem é produzida e consumida. De acordo com Kress e van Leeuwen (2006), alguns marcadores de modalidade são: i) saturação da cor: ii) diferenciação da cor; iii) modulação da cor; iv) contextualização; v) representação; vi) profundidade; vii) iluminação; e viii) brilho. Esses marcadores não podem ser mensurados quantitativamente, mas analisados com base em um continuum, que vai da ausência total à presença total do marcador.

A metafunção composicional trata do "potencial das imagens para captar participantes, processos e circunstâncias em composições visuais e layouts que, por convenção social, estão atrelados a pesos informativos" (HENGES; NASCIMENTO; MARQUES, 2013, p. 244). Sendo assim, a maneira como os padrões de representação e os padrões de interação se articulam para formar um todo significativo, um gênero visual, um texto multimodal, diz respeito à metafunção composicional. De acordo com Kress e van Leeuwen (2006), essa articulação é feita por meio de três sistemas inter-relacionados: i) disposição espacial; ii) saliência; e iii) molduragem.

A disposição espacial dos participantes representados e/ou dos eventos no espaço da imagem, conforme Kress e van Leeuwen (2006), revela o valor informativo da imagem. Esse valor está relacionado às diferentes zonas da imagem (direita - esquerda; superior - inferior; centro - margem) e com os valores específicos atribuídos a cada uma delas pela sociedade e dentro de cada cultura. A saliência diz respeito aos diferentes recursos, tanto representacionais quanto interacionais que são empregados para atrair a atenção do espectador (lugar dos participantes no primeiro plano ou no plano de fundo; tamanho relativo; contrastes de tom ou de cor, p. ex.). A molduragem realiza a conexão ou não entre os elementos da imagem, por meio de elementos que criam linhas divisórias ou pelas linhas reais da imagem.

Tendo apresentado brevemente as metafunções realizadas pelo modo semiótico visual (KRESS; VAN LEEUWEN, 2006), apresentamos a seguir 
algumas considerações sobre o Sistema de Avaliatividade (MARTIN; WHITE, 2005), que explora a metafunção interpessoal (HALLIDAY; MATTHIESSEN, 2004) do modo semiótico verbal, a fim de investigar a "organização sistêmica do modo como os falantes/escreventes expressam pensamentos, sentimentos, opiniões e atitudes sobre algum objeto, fenômeno, evento, pessoa, etc." (LIMA; COROA, 2010, p. 127).

\section{Sistema de Avaliatividade}

O estudo da avaliação no modo semiótico verbal enfoca a construção de textos por comunidades de valores e campos compartilhados de posse de mecanismos linguísticos capazes de expressar emoções, tarefas e ordens (MARTIN; WHITE, 2005). A avaliação emana da maneira como o escritor ou falante se posiciona em relação ao seu leitor ou interlocutor e da forma como os fatos e os participantes representados são julgados. Ela está, portanto, diretamente relacionada à metafunção interpessoal (HALLIDAY; MATTHIESSEN, 2004). Em termos léxico-gramaticais, a avaliação revela os tipos de atitudes negociadas no texto, bem como a força dos sentimentos em relação ao objeto de avaliação (VIAN JR., 2009, p. 100). Embora a avaliação possa ser mais explicitamente percebida em nível léxico-gramatical, sua abrangência alcança, especialmente, o nível semântico-discursivo.

Os primeiros estudos sobre avaliação no modo semiótico verbal, de acordo com Orlando Vian Jr. (2009, p. 100-101), datam do final da década de 1970 e início da década de 1980. A proposta de Martin e White (2005), que será enfocada neste artigo, busca situar a avaliação e a avaliatividade ${ }^{3}$ dentro de um modelo holístico de linguagem e contexto social. Por isso, seu modelo teórico baseia-se no sistema geral da Linguística Sistêmico-Funcional

\footnotetext{
3 Vian Jr. (2009, p. 103) procura distinguir os termos avaliação e avaliatividade. A partir da noção de escala de instanciação (Halliday; Matthiessen, 2004), o autor propõe que "a avaliação é apenas a instanciação das opções avaliativas de que a língua dispõe como potencial de significados presentes no texto, ao passo que avaliatividade está relacionada a todo o potencial que a língua oferece para realizarmos significados avaliativos, ou seja, para expressarmos pontos de vista positivos ou negativos, para graduarmos a força ou o foco do que expressamos e para negociarmos a intersubjetividade e assim por diante".
} 
(HALLIDAY; MATTHIESSEN, 2004). Para dar conta da avaliação e da avaliatividade no modo semiótico verbal, Martin e White (2005) focalizam especialmente os significados interpessoais em textos verbais escritos.

Além da perspectiva metafuncional, outro conceito fundamental para o Sistema de Avaliatividade, também advindo da Linguística Sistêmico-Funcional (HALLIDAY; MATTHIESSEN, 2004), é o de realização. Embora a avaliatividade seja alocada no estrato do discurso e da semântica, os estratos da grafologia e fonologia e da léxico-gramática são fundamentais para a tessitura dos sentidos avaliativos ao longo do processo comunicativo. Por isso, a preocupação de Martin e White (2005) em propor um modelo global que leve em consideração a linguagem em todos os seus estratos, bem como o contexto social.

Conforme Martin e White (2005, p. 10-11), o estrato do discurso e da semântica é considerado o estrato da avaliatividade por três razões principais: i) a realização de uma atitude tende a estender-se ao longo das fases do discurso, independentemente das fronteiras gramaticais; ii) uma dada atitude pode ser realizada por meio de uma gama de categorias gramaticais; e iii) a metáfora gramatical é o processo pelo qual o significado é processado duas vezes, introduzindo uma tensão entre palavra (léxico-gramatica) e significado (semântica do discurso).

Juntamente com a concepção metafuncional da linguagem e com a concepção de realização, a noção de instanciação, também advinda da perspectiva sistêmico-funcional (HALLIDAY; MATTHIESSEN, 2004), é fundamental para o Sistema de Avaliatividade. Enquanto a realização é uma escala de abstração, envolvendo a recodificação de um padrão de significados em outro, a instanciação é uma escala de generalização envolvendo inércia e mudança. Segundo Vian Jr. (2009, p. 109), "a instanciação é a manifestação do sistema linguístico no texto, o que deve da mesma forma, ser interpretado como um processo dialético, dado ao fato de que a instanciação se manifesta, constrói e reconstrói os potenciais de significado de determinada cultura". 
Considerando todo o potencial semântico discursivo que envolve a avaliação no modo semiótico verbal e enfocando a realização dos recursos avaliativos, Martin e White (2005) puderam categorizar as ocorrências avaliativas e, assim, propor o Sistema de Avaliatividade. Segundo esse mapeamento, quando produzimos discursos lançamos mão de três sistemas simultâneos principais para expressar a avaliação: i) atitude; ii) gradação; e iii) engajamento.

Assim, de acordo com o sistema proposto por Martin e White (2005), dentre os recursos disponíveis no sistema, podemos escolher expressar nossas atitudes avaliativas por meio das categorias do: i) afeto: expressão de sentimentos e emoções (p. ex.: Ouvir sirenes deixa-o transtornado); ii) julgamento: ponderações de caráter (p. ex.: É teimoso como uma porta); e iii) apreciação: atribuição de valor às coisas ( $p$. ex.: Este livro é fantástico). Podemos também selecionar o recurso da gradação para aumentar ou diminuir o grau de nossa avaliação (p. ex.: Foi o livro mais lindo que li, causou-me imenso prazer; Os jovens são desleixados mesmo.) ou, ainda, optar por indicar, por meio do engajamento, a fonte de nossa avaliação (p. ex.: Nunca houve tanta corrupção; Acredito que não haja problemas em você não ir à festa).

O Sistema de Avaliatividade, portanto, dá conta de questões linguísticas de posicionamento interpessoal, ou seja, de como manifestamos nossas opiniões em um texto falado ou escrito. Os três subsistemas da Avaliatividade atitude, engajamento e gradação - possuem categorias específicas, permitindo aumentar o grau de aprofundamento da análise de um texto, caso se faça necessário (Figura 1). 
Figura 1 - Sistema de Avaliatividade

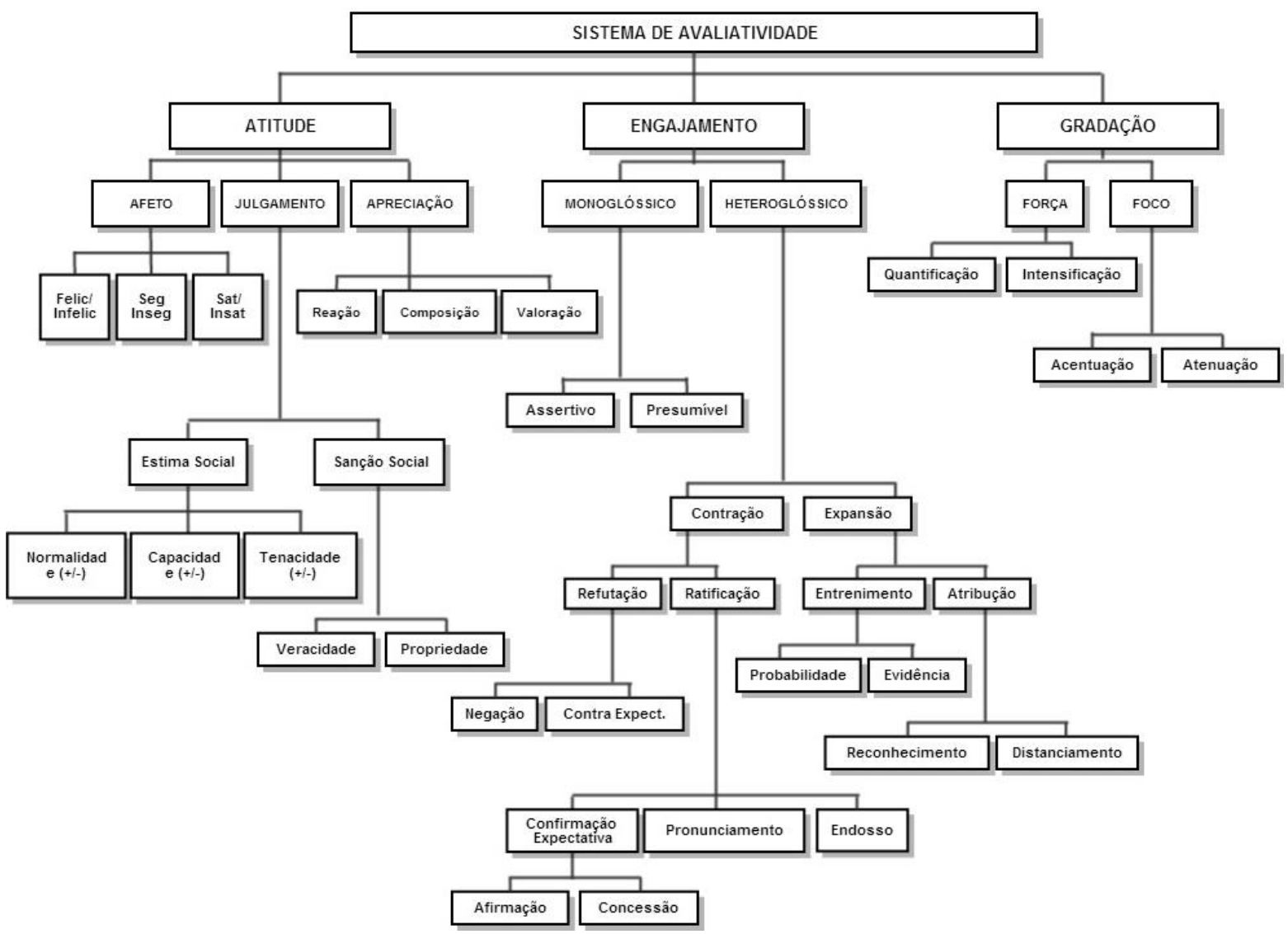

Fonte: Martin e White (2005); Ninin e Bárbara (2013, p. 131).

De acordo com Martin e White (2005), o engajamento pode ser: i) monoglóssico4; ou ii) hetereglóssico. A atitude, como já mencionado, pode ser de: i) afeto; ii) julgamento; ou iii) apreciação. Já a gradação pode ser de: i) força (quantificação ou intensificação); ou ii) foco (acentuação ou atenuação). Na Figura 1, apresentamos o Sistema de Avaliatividade, seus subsistemas e suas categorias semânticas específicas.

O subsistema de atitude "abrange três regiões semânticas, envolvendo o que é tradicionalmente denominado emoção, ética e estética" (MARTIN; WHITE, 2005, p. 42). A emoção, cerne dessas regiões semânticas, é

\footnotetext{
${ }^{4}$ Ninin e Bábara (2013) apresentam o subsistema de engajamento com base em Martin e White (2005, p. 122-134) e White (2011, p. 1). White (2011) expande o engajamento monoglóssico, subdividindo-o em assertivo e presumível.
} 
denominada afeto e coloca em causa o registro de sentimentos negativos e positivos. Atitudes que admiramos, condenamos ou criticamos estão relacionadas ao comportamento e são denominadas julgamento. A apreciação envolve a valoração de fenômenos semióticos e naturais.

Quando os recursos linguísticos que permitem adotar uma posição em relação àquilo que referenciamos pela linguagem ou àqueles para quem direcionamos nosso discurso são acionados, estamos dando pistas do nosso engajamento (MARTIN; WHITE, 2005). O envolvimento do falante/escritor com suas proposições e seu público é um processo dialógico perceptível no conjunto total do texto. $O$ engajamento é heteroglóssico "quando recorre aos recursos que permitem espaço para alternativas dialógicas; ou é monoglóssico, quando esses espaços não são abertos no texto" (NININ; BÁRBARA, 2013, p. 130).

De acordo com Martin e White (2005, p. 136), a gradação é o subsistema central no Sistema de Avaliatividade, pois atitude e engajamento seriam domínios da gradação que variam de acordo com a natureza dos significados que estão sendo apresentados. Há dois eixos de escala que são acionados pela gradação: i) força (intensidade e quantidade); e ii) foco (prototipicidade e precisão). A categoria semântica da força, portanto, envolve declarações inerentemente de gradação (positivo/negativo) e de tamanho, vigor, proximidade, isto é, de intensidade e quantidade. Já a categoria semântica do foco envolve os fenômenos prototípicos que normalmente não poderiam ser graduados.

Conforme enfatizamos, o Sistema de Avaliatividade proposto por Martin e White (2005) enfoca o modo semiótico verbal escrito, o que não significa que outros modos semióticos não possuam recursos para a realização da avaliação. Economou (2009), por exemplo, demonstrou como as categorias avaliativas ocorrem em imagens da imprensa.

\section{Avaliatividade em imagens}


Levando em consideração o Sistema de Avaliatividade estabelecido por Matin e White (2005) para a linguagem verbal, Economou (2009) propôs um estudo da avaliatividade em imagens de imprensa. Por questões de objetividade e de espaço, revisaremos os aspectos mais relevantes de seu estudo, especialmente as proposições sobre as categorias que realizam os subsistemas da avaliatividade em imagens.

Sobre a atitude em imagens da imprensa, Economou (2009) contraria Kress e van Leeuewen (2006), propondo que, tanto na interação entre participante(s) representado(s) e participante(s) interativo(s), quanto na interação social representada por meio dos participantes humanos da imagem, a avaliação é um aspecto de significado interpessoal mais relevante do que a própria interação. Nesse sentido, Economou (2009) sumariza que imagens jornalísticas apresentam alto perfil representacional e que isso seria o gatilho para a naturalização de uma "posição de atitude" dos telespectadores.

Segundo Economou (2009), a atitude visual de uma imagem jornalística é complexa e poderosa, podendo apresentar tanto atitude visual explícita quanto atitude visual implícita. A atitude visual explícita limita-se ao que pode ser inscrito em ou por um participante representado. A atitude visual implícita inclui os valores atribuídos pelos telespectadores aos participantes representados bem como os valores evocados no espectador pelos itens descritos.

Quanto aos subsistemas da atitude, Economou (2009) destaca que a apreciação visual pode ser evocada pela ideação e ser representada pela imagem jornalística como um artefato, isto é, uma coisa. $O$ afeto e suas subcategorias (as mesmas do modo semiótico verbal) são facilmente identificáveis na expressão facial dos participantes, entretanto, algumas expressões específicas podem ser ambiguamente identificadas devido a outros aspectos avaliativos presentes na imagem. $O$ julgamento, quando em atitude objetiva, é monoglóssico e em atitude subjetiva heteroglóssico. A heteroglossia ocorre somente por meio de expansão dialógica. Assim, a atribuição se dá pela 
incorporação de elementos verbais ou outros elementos imagéticos (um pôster, cartaz, pano de fundo, efeito, p. ex.) à imagem jornalística ou pela substituição de uma imagem por outra. $O$ entretenimento está diretamente ligado à atitude autoral subjetiva, determinada pelo enquadramento da foto.

Em relação à gradação, Economou (2009, p. 157) afirma que, além do potencial de atitude do conteúdo representacional de uma imagem, a forma de composição/organização desse conteúdo pode posicionar 0 espectador atitudinalmente. Esses valores de atitude podem ser sinalizados pela maneira como os significados representacionais são classificados ou escalonados. Da mesma forma que os "diferentes tipos de intensificação na linguagem [verbal], as escolhas visuais do ângulo da câmera e posição podem aumentar ou diminuir a força ou impacto de um item de representação em uma imagem jornalística, e também de quaisquer significados interpessoais" (Economou, 2009, p. 160).

Assim, o sistema de gradação visual escala os significados ideacionais de duas maneiras: i) pela expressão visual textual: luz, cor e escolhas de foco; e ii) pela expressão visual espacial: ângulos e tamanho do quadro da câmera. 0 foco (expressão visual textual) tem a ver com a identificação visual de uma forma, vetor ou variação como uma opção ideacional específica. Alto foco pode criar envolvimento interpessoal em um item, mantendo a atenção do espectador, isto é, onde um item é altamente especificado há mais informação visual disponível, permitindo a categorização mais precisa do elemento. Quanto à força (expressão visual espacial), um item ideacional visual pode ser escalonado para cima ou para baixo por sua quantificação (p. ex., tornando-se maior ou menor), e também por sua intensificação (p. ex., tornando-se mais brilhante ou mais maçante). A repetição é um artefato que envolve a presença de dois ou vários itens representacionais semelhantes na imagem, aumentando, assim, a força.

A respeito do engajamento visual, Economou (2009, p. 197-261) afirma que a existência de engajamento monoglóssico e heteroglóssico segue a 
mesma lógica do modo semiótico verbal. Entretanto, no engajamento heteroglóssico não há contração dialógica, apenas expansão, o que resulta na existência de duas categorias semânticas apenas: entretenimento e atribuição. Tendo em vista as categorias representacionais, interativas e composicionais do modo semiótico visual (KRESS; VAN LEEUWEN, 2006) e as categorias do Sistema de Avaliatividade propostas por Martin e White (2005) para o modo semiótico verbal e investigadas por Economou (2009) no modo semiótico visual, propomos a investigação de cinco imagens jornalísticas do contexto brasileiro, conforme detalhamos a seguir.

\section{Metodologia}

A coleta das imagens obedeceu a dois critérios: i) proeminência das imagens; e ii) recência das imagens. Foram coletadas imagens vencedoras de concursos jornalísticos importantes no cenário brasileiro e internacional nos últimos 13 anos, até 2013 (Quadro 3). A fim de facilitar a referência às imagens coletadas, criamos códigos de identificação, conforme detalhamos a seguir: i) o primeiro elemento do código indica, em letra maiúscula, a letra inicial do sobrenome do autor da imagem: $\mathrm{T}=$ Tavares; $\mathrm{S}=$ Souza; $\mathrm{A}=$ Alves; $\mathrm{e} \mathrm{C}=$ Corredo; ii) o segundo elemento do código indica os dois últimos algarismos do ano de publicação da imagem: $13=2013 ; 12=2012$; e $02=2002$; iii) 0 terceiro elemento do código é um sinal de sustenido (\#), a ser lido como "número"; e iv) o quarto elemento do código indica, em ordem decrescente, da mais recente para a mais antiga, o número referente a cada uma das imagens.

Quadro 3 - Codificação das imagens coletadas para a pesquisa

\begin{tabular}{l|l|l|l}
\hline CóDIGO & \multicolumn{1}{|c|}{ CONCURSO } & \multicolumn{1}{c|}{ AUTOR } & \multicolumn{1}{c}{ ANO } \\
\hline T13\#1 & $58^{\circ}$ Prêmio Esso de 2013 & $\begin{array}{l}\text { Victor Dragonetti } \\
\text { Tavares }\end{array}$ & 2013 \\
\hline S13\#2 & $\begin{array}{l}\text { 30 } \\
\text { Jornalismo }\end{array}$ & 2013 \\
\hline A13\#3 do Prêmio Rei da Espanha de & $10^{\circ}$ Prêmio Líbero Badaró de Jornalismo & Wilton Souza Junior & 2013 \\
\hline
\end{tabular}




\begin{tabular}{l|l|l|l}
\hline S12\#4 & $\begin{array}{l}570 \text { Prêmio Esso de Jornalismo } \\
290 \text { Prêmio Internacional de Jornalismo Rei da } \\
\text { Espanha }\end{array}$ & Wilton Souza Junior & 2012 \\
\hline C02\#5 & $\begin{array}{l}9^{\circ} \text { Prêmio Líbero Badaró de Jornalismo } \\
40 \text { Prêmio Imprensa Embratel } \\
470 \text { Prêmio Esso de Jornalismo }\end{array}$ & Wânia Corredo & 2002 \\
\hline
\end{tabular}

Fonte: Elaborado pela autora.

Quanto aos procedimentos e categorias de análise do corpus, os contextos reais e de recontextualização (BERNSTEIN, 1988) das imagens foram investigados, priorizando o contexto em que as imagens foram publicadas (recontextualização) para a análise das ocorrências avaliativas. Em seguida, as imagens foram analisadas metafuncionalmente, almejando descrever seus significados representacionais, interativos e composicionais com base na Gramática do Design Visual, proposta por Kress e van Leeuwen (2006). Posteriormente, com base nos dados obtidos na análise preliminar e a partir das categorias semânticas propostas por Martin e White (2005) para o Sistema de Avaliatividade em linguagem verbal e com base nos pressupostos de Economou (2009) para a análise da avaliatividade em imagens jornalísticas, foram identificadas, analisadas e descritas as categorias avaliativas encontradas nas imagens do corpus.

\section{Resultados e Discussão}

Nesta seção, apresentamos os resultados da análise do corpus investigado neste estudo e a discussão dos dados obtidos. Expomos cada uma das imagens selecionadas para esta pesquisa e tratamos, brevemente, do contexto de publicação e de execução de cada imagem, a fim de obtermos uma visão abrangente sobre as imagens selecionadas, e que possa nos auxiliar a investigar as realizações léxico-gramaticas e semânticas da avaliação em imagens. Em seguida, exibimos os resultados referentes à análise metafuncional de cada imagem pela perspectiva da Gramática do Design Visual (KRESS; VAN LEEUWEN, 2006). Posteriormente, visto que o intuito deste 
estudo é identificar categorias avaliativas recorrentes em imagens jornalísticas, apresentamos os resultados encontrados na análise dos subsistemas de atitude, engajamento e gradação (MARTIN; WHITE, 2005; ECONOMOU, 2009) de cada imagem.

As imagens selecionadas para este estudo apresentam uma oposição entre "discurso real", isto é, discurso quando no contexto primário de produção, e "discurso imaginário" (BERNSTEIN, 1988, p. 63), referente ao texto quando recontextualizado. Embora o enfoque de nossa análise seja a imagem recontextualizada - discurso imaginário - é imprescindível conhecermos o discurso real para a compreensão dos movimentos de recontextualização discursiva, e para a compreensão de como a mediação que relaciona o texto original a outras lógicas e objetivos permite uma intervenção ideológica direcionada para o controle dos novos contextos.

Quanto ao contexto de produção e recontextualização do corpus, a imagem T13\#1 (Figura 2) foi registrada em junho de 2013, em São Paulo, pelo repórter-fotográfico Vitor Dragonetti Tavares, do coletivo Se/vaSP, durante as manifestações populares que agitaram o Brasil naquele período. A imagem registrou o momento em que um policial, ferido na cabeça, imobilizava um manifestante e apontava a arma para o grupo que havia acabado de agredi-lo. Essa imagem recebeu o título de "PM ferido afasta agressores" e foi publicada nos jornais Folha de São Paulo e Estado de S. Paulo de 13 de junho de 2013.

Figura 2 - Imagem T13\#1

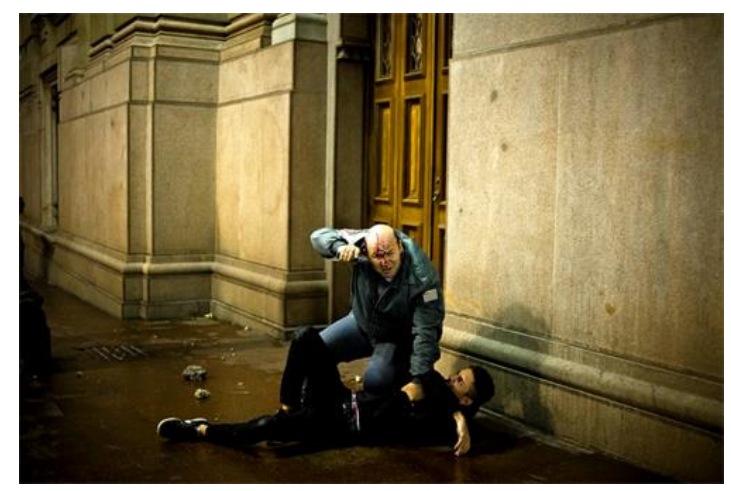

Fonte: O Governo ... (2013). Foto Vitor Dragonetti Tavares. 
Do ponto de vista representacional, a imagem T13\#1 pode ser classificada como narrativa de reação não-transacional, isto é, há um Reator, mas não há um Fenômeno representado. Nessa imagem, fica claro como, na recontextualização, uma imagem pode ser manipulada, especialmente no que diz respeito aos significados composicionais, e ser empregada como "gatilho" para impulsionar a leitura da matéria jornalística, aumentando, inclusive, a venda de exemplares do jornal. Nesse caso, por exemplo, o reenquadramento possibilitou o apagamento do Fenômeno. A relação entre participantes interativos e participantes representados é realizada pela oferta de informação, pela atitude subjetiva e pela relação de igualdade social entre participantes representados e participantes interativos.

Os resultados da análise da avaliatividade demonstraram que a atitude visual é explicitamente inscrita na imagem T13\#1. Visualmente, a expressão facial e corporal dos participantes representados revela atitudes de afeto, como o sentimento de medo e de ameaça que os participantes parecem estar experimentando. Nessa imagem, ocorre julgamento explícito de sanção social, pois um policial ferido é representado imobilizando um homem e ameaçando com uma arma alguém que não aparece representado. Esse comportamento poderia ser compreendido negativamente e gerar atribuições de valor à atitude do policial ou, por outro lado, ser compreendido positivamente, criando julgamentos negativos sobre o Fenômeno, que, nessa imagem, embora não seja representado, é recuperável por meio da manchete relacionada à imagem.

A apreciação em imagens está intimamente ligada ao julgamento. Sendo assim, em T13\#1, tanto é possível emitir um julgamento sobre o comportamento do policial ou do manifestante imobilizado, que, de certa forma representa o Fenômeno subentendido, quanto apreciar 0 produto do comportamento de um e/ou de outro participante representado. Em grande medida, o julgamento é direcionado pelo engajamento do fotógrafo ou do 
editor da imagem no momento de sua recontextualização. Por isso, podemos dizer que o julgamento em T13\#1 é heteroglóssico.

A imagem S13\#2 foi registrada pelo repórter-fotográfico Wilton Silva Junior na Academia Militar das Agulhas Negras, em Resende (RJ), por ocasião da participação da presidente Dilma Rousseff do cerimonial de entrega de espadins a 411 cadetes. Essa fotografia foi originalmente publicada na edição do dia 21 de agosto de 2011 do periódico O Estado de São Paulo, vinculada à seguinte manchete: "Descontentes com tratamento do PT e receosos sobre empenho da presidente para manter aliança, dirigentes preparam candidaturas".

Figura 3 - Imagem S13\#2

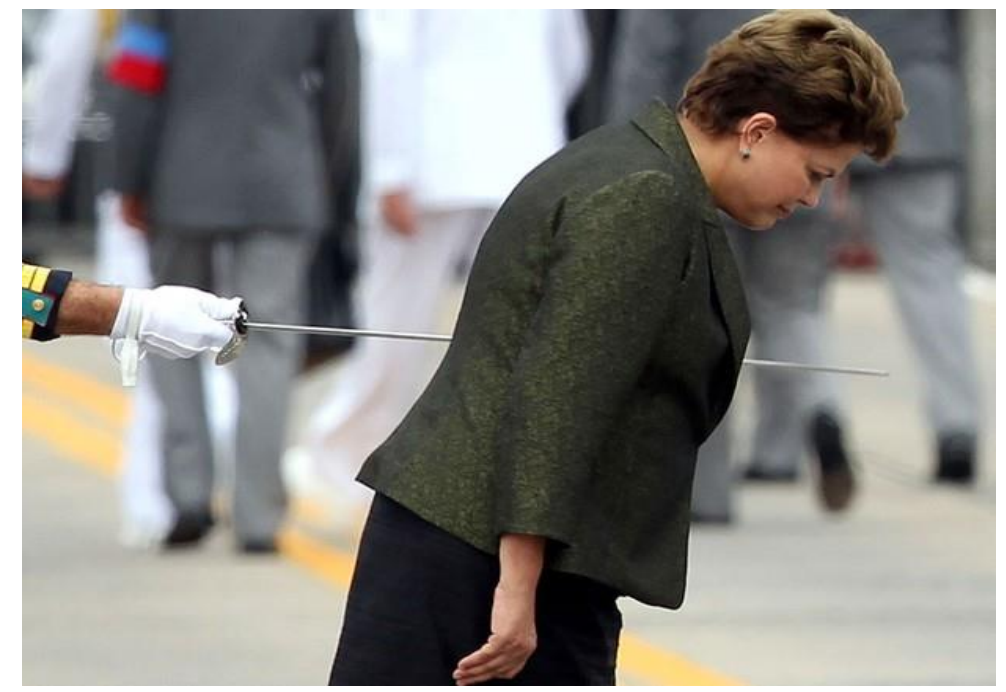

Fonte: Domingos (2011). Foto Wilton Silva Junior.

A imagem S13\#2 sugere que a presidente Dilma tenha sido atravessada por uma espada, por isso, do ponto de vista representacional, é denominada conceitual simbólica sugestiva. O contato ocorre pela oferta, a atitude é subjetiva, o enquadramento apresenta somente o Portador, no caso a presidente, numa relação de igualdade social com os participantes interativos.

O foco apaga o momento específico da imagem, criando uma abstração (ECONOMOU, 2009), que, na recontextualização, ganha novo sentido. A atitude visual é implicitamente provocada na imagem, pois não podemos identificar os 
sentimentos experimentados pelo participante representado. Imagens recontextualizadas artisticamente, como é o caso da imagem S13\#2, apresentam um tipo específico de julgamento. S13\#2 captura um momento de ilusão de ótica e, além disso, foi manipulada graficamente para criar a sensação de que a presidente Dilma está sendo atravessada por uma espada, portanto, cria uma metáfora visual representacional, que porta em si um juízo de valor autoral e que provoca no leitor um julgamento, neste caso de estima social, colocando em dúvida as capacidades da presidente Dilma para realizar suas funções. Por conta de todo esse processo de manipulação da foto e pelos recursos usados pelo fotógrafo, podemos inferir que o engajamento em S13\#2 é heteroglóssico.

A imagem A13\#3, com o título "Santa Maria, 27/01/2013", foi capa do jornal Zero Hora do dia 28 de janeiro de 2013, um dia após o incêndio que vitimou 242 jovens em uma casa noturna de Santa Maria (RS). O reconhecimento dos corpos e velório coletivo das vítimas foi realizado em um ginásio de esportes da cidade de Santa Maria, onde o fotógrafo Lauro Alves registrou o momento em que uma jovem, usando o chapéu do namorado morto na tragédia, chora debruçada sobre o seu caixão.

Figura 4 - Imagem A13\#3 


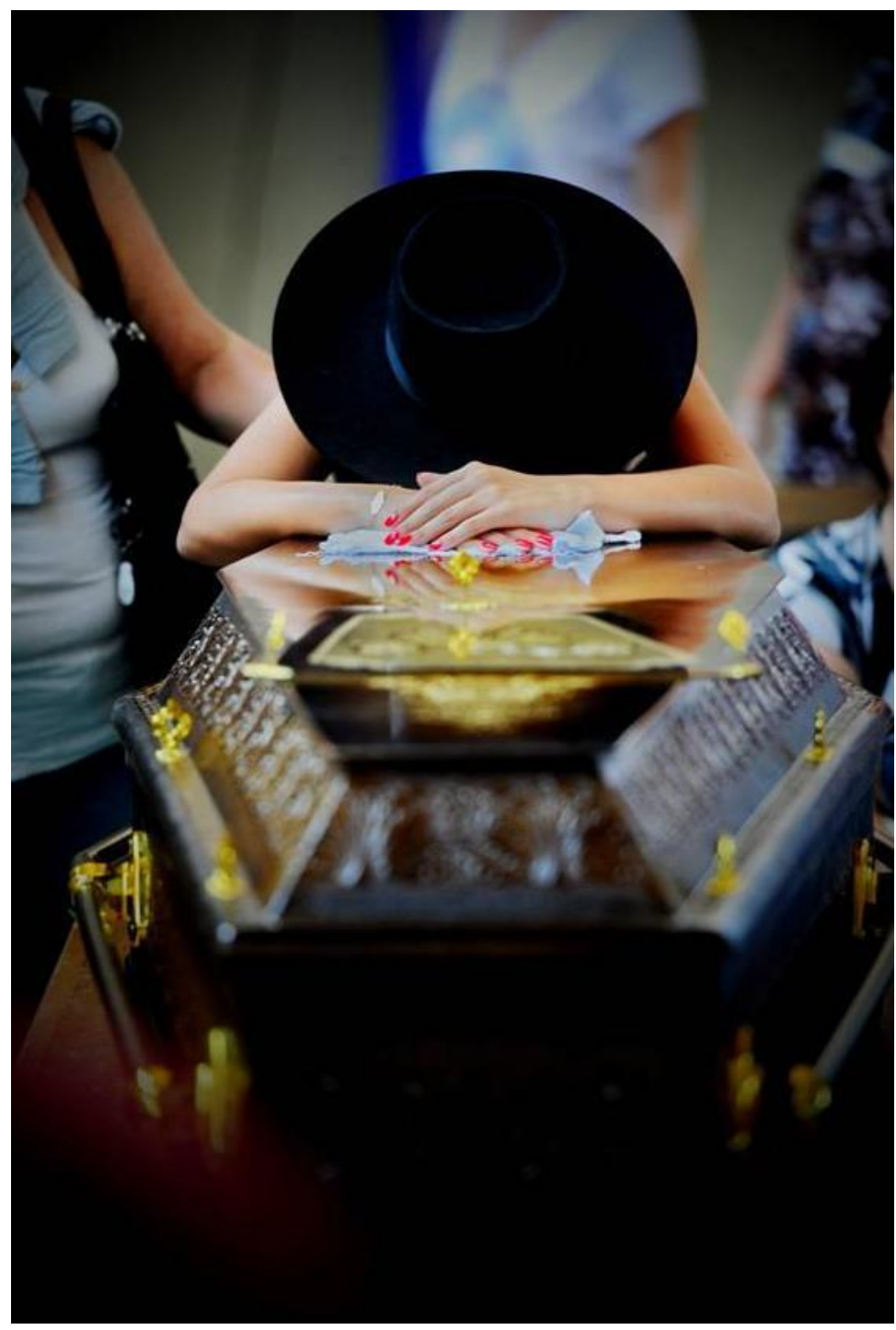

Fonte: Truda e Menezes (2015). Foto Lauro Alves.

A imagem A13\#3 pode ser classificada como narrativa de ação nãotransacional, representando um processo mental de afeto. A moça que chora a morte do namorado é o Experenciador da dor, da perda e do luto, sentimentos que configuram o Fenômeno experenciado. Do ponto de vista da interação, a imagem é de oferta, a atitude subjetiva, sem relação hierárquica entre participante representado e interativo, pois a imagem está ao nível dos olhos. A composição dessa imagem também é importante para a construção do sentido. Podemos observar o uso do recurso de saliência nas mãos da participante representada principal, cujas unhas vermelhas sugerem a noção de festa, 
alegria. O caixão, por outro lado, embora esteja em primeiro plano está fora de foco, bem como os demais participantes, dando premência para o Experenciador e para aquilo que ele sente, demonstrado, principalmente, por seu posicionamento corporal.

$\mathrm{Na}$ imagem A13\#3, portanto, a atitude visual é implicitamente provocada. A imagem pode ser entendida como um artefato. Assim, vista integralmente, provoca uma apreciação negativa no leitor de cultura ocidental, que associa a representação do caixão e a linguagem corporal da participante representada à ideia de tristeza, luto, perda de um ente querido. Na imagem, por conta das escolhas realizadas pelo fotógrafo e pelos responsáveis por sua recontextualização, o engajamento pode ser definido como heteroglóssico. A gradação é notável no foco que se dá ao chapéu e às unhas vermelhas da jovem e na força dada pelo enquadramento. $O$ chapéu remete ao namorado morto, as unhas ao momento festivo do qual participavam antes da tragédia e o enquadramento busca expressar, por meio dessa cena, a dor de todas os outros amigos e familiares presentes no local onde estavam sendo velados os corpos.

A imagem S12\#4, de Wilton Silva Junior, foi publicada em matéria do Jornal O Estado de São Paulo, de 24 de junho de 2012, vinculada à manchete "Índios adotaram estratégias diferentes". A imagem mostra um grupo indígena, durante a Rio+20, atravessando uma rua do Rio de Janeiro em um ato em defesa dos interesses de sua comunidade. Essa imagem conferiu ao repórterfotográfico, pelo segundo ano consecutivo, o Prêmio Rei da Espanha de Jornalismo.

Figura 5 - Imagem S12\#4 


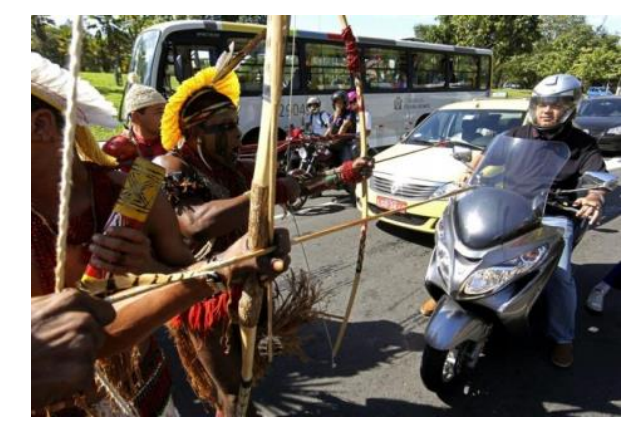

Fonte: Leal (2012, p. H6). Foto de Wilton Silva Junior.

No que concerne à representação, a imagem S12\#4 representa um Ator (grupo indígena empunhando arcos e flechas) e uma Meta (motoristas que trafegam por uma avenida), portanto é uma imagem narrativa transacional. Como os motoristas não reagem à ação dos indígenas, esta é uma imagem unidirecional. $\mathrm{O}$ enquadramento da imagem é de tomada média, propiciando a oferta da imagem por meio da atitude subjetiva do fotógrafo.

Os resultados da análise demonstraram que a atitude visual na imagem S12\#4 é explicitamente inscrita. A expressão facial e corporal dos participantes representados na imagem revela atitudes de afeto, como raiva e espanto/indiferença. Nessa imagem, ocorre julgamento explícito de sanção social, isto é, representa-se uma atitude de um grupo de participantes socialmente entendido como negativa, pois eles estão atacando alguém. Assim, a imagem pode desencadear julgamento implícito negativo do leitor que, conforme suas concepções ideológicas, poderá julgar mal o jornal que representa um grupo indígena atacando transeuntes, os próprios indígenas ou, ainda, os transeuntes.

Tanto é possível expor um julgamento sobre o comportamento do grupo indígena contra o pano de fundo dos valores sociais que possuímos, quanto apreciar o produto desse comportamento (bom, ruim, aceitável, inaceitável). $\mathrm{Na}$ imagem S12\#4, o engajamento é heteroglóssico, pois foi realizada uma escolha de enquadramento por parte dos seus produtores, o que revela um posicionamento. Há presença de repetição nessa imagem, artifício de gradação 
bastante recorrente em imagens, segundo Economou (2009). Os indígenas são representados como grupo por meio dessa repetição.

A imagem C02\#5 foi capa do Jornal Extra, do dia 30 de dezembro de 2002, um dia após a fotógrafa Wânia Corredo ter registrado a execução de um desenhista de móveis no bairro do Benfica, no Rio de Janeiro. Wânia e sua equipe retornavam da finalização de outra reportagem, quando ouviram alguns disparos oriundos de uma arma portada por um de dois rapazes montados em uma motocicleta. Imediatamente, Wânia apanhou sua câmera e registrou os dois últimos disparos que mataram o desenhista. Dias depois, a foto auxiliou na identificação e posterior prisão dos criminosos. Não encontramos a matéria jornalística juntamente com a qual a imagem foi originalmente publicada.

\section{Figura 6 - Imagem S12\#4}

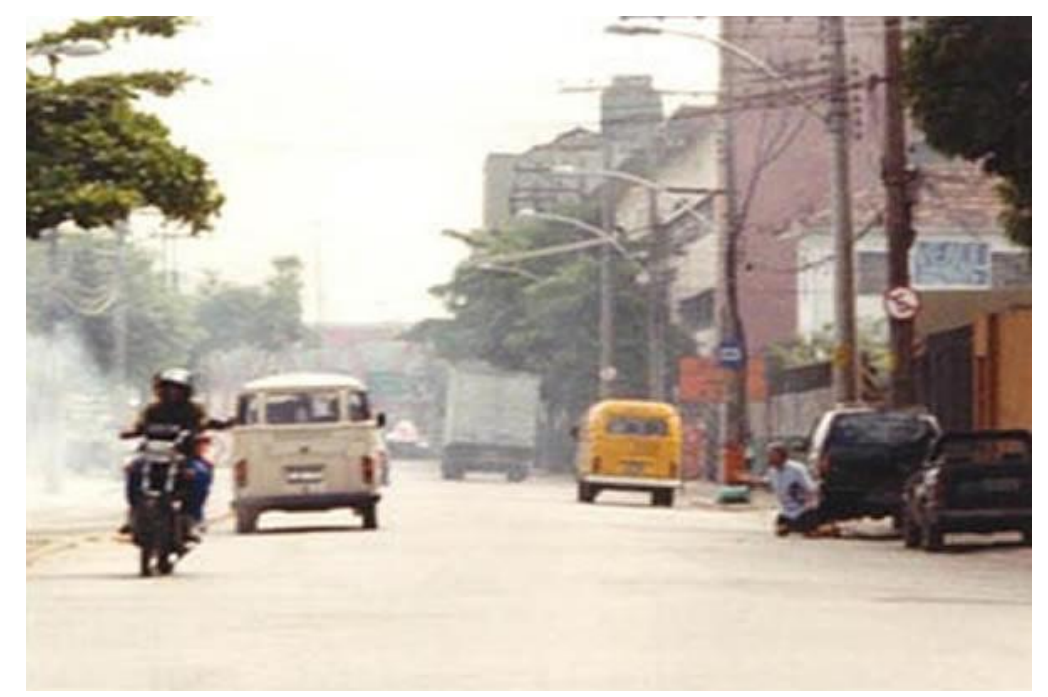

Fonte: O Buteco da Net (2011). Foto: Wânia Corredo (2002).

A imagem C02\#5 narra uma ação transacional unidirecional, isto é, os bandidos que atiram são Atores e a vítima, que não reage à ação, é a Meta. Essa imagem tem a particularidade de apresentar atitude objetiva, ou seja, o cenário é ofertado na íntegra por meio de longa tomada de câmera e da distância social distante. Todos os elementos representacionais, interacionais e 
composicionais contribuem para o sentido de uma imagem realizada com base em um flagrante.

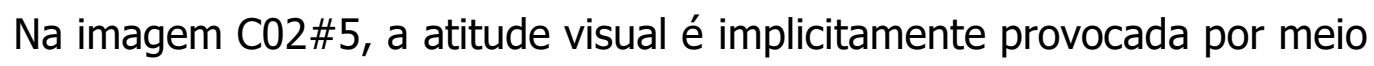
da criação de uma metáfora representacional: a representação de um homem ajoelhado, paralisado pela ação de outros dois participantes. Essa imagem revela uma categoria de afeto bastante específica de imagens, segundo Economou (2009). Nesse caso, as expressões faciais dos participantes representados não são nítidas, entretanto, por meio da composição imagética, o participante interativo pode deduzir qual é o afeto representado na imagem e experimentar esse sentimento. Esse efeito pode ser denominado afeto compartilhado (ECONOMOU, 2009, p. 116), pois envolve o participante interativo de forma que a imagem funcione como um "gatilho" imagético que desencadeará nele reações positivas ou negativas.

Em C02\#5, o engajamento é monoglóssico, visto que a tomada de câmera é objetiva. Por isso, também, a gradação é fraca, pois nem o foco nem a força forma usados para destacar um elemento em especial.

Em nosso corpus, a predominância de atitude visual implícita provocada sugere que, em imagens, a liberdade interpretativa está vinculada ao conhecimento compartilhado entre participante(s) representado(s) e participante(s) interativo(s). Além disso, o modo semiótico visual pode ser mais denso do que o modo semiótico verbal, oferecendo, ao mesmo tempo e em um mesmo ponto de realização, mais de um item atitudinal para interpretação.

Observamos que as atitudes de afeto podem apresentar categorias semelhantes às da linguagem verbal (felicidade / infelicidade; segurança / insegurança e satisfação / insatisfação), entretanto, por conta das questões próprias às imagens jornalísticas, como recontextualização, abstração e manipulação da imagem "real", algumas emoções podem ser ambiguamente identificadas. Na imagem T13\#1, por exemplo, temos um caso de afeto de insegurança no participante representado como policial e de infelicidade no participante dominado pelo policial, mas quando consideramos a 
recontextualização da imagem em uma reportagem que trata de abuso policial, pode-se pensar em uma inversão de tais avaliações.

Os resultados revelam que uma imagem pode representar várias atitudes concomitantes, por isso o julgamento em imagens está fortemente ligado ao afeto e à apreciação. Quando o julgamento é explícito, está ligado à representação de comportamentos de participantes humanos. Implicitamente, 0 julgamento é evocado no participante interativo e depende do conhecimento e dos valores compartilhados entre ele e o produtor da imagem.

A análise do corpus demonstrou que a apreciação é exclusivamente evocada, pois em imagens não é possível, quando envolvendo participantes representados, determinar se ocorre julgamento de um comportamento ou apreciação do produto oriundo dele. Além disso, em imagens, assim como na linguagem verbal, o alvo da apreciação pode ser uma coisa ou uma parte do corpo, uma característica física, um cenário, isto é, elementos secundários que evocam apreciação, conjuntamente com julgamento e afeto, em alguns casos.

De acordo com nossos resultados, a apreciação está diretamente ligada ao leitor e à capacidade que a imagem tem de, como na linguagem verbal, provocar-lhe uma reação positiva ou negativa, uma valoração ou prazer derivado da composição imagética. No entanto, é importante salientar que o posicionamento ideológico do leitor pode interferir decisivamente sobre o polo da apreciação, se positivo ou negativo, alterando-o. Observamos que imagens possibilitam uma visão segmentada - análise dos seus elementos separadamente - ou uma visão global quanto à apreciação. Quando tomada globalmente, a imagem torna-se em si um objeto (independentemente de representar objetos ou pessoas) e esse artefato passa então a ser apreciado.

Os resultados desta investigação revelaram que visualmente o engajamento, assim como em linguagem verbal, pode ser monoglóssico ou heteroglóssico. $O$ engajamento visual será monoglóssico quando a imagem puder substituir o olhar humano, ou seja, quando a representação fotográfica capturar o mundo real da maneira mais naturalística ou objetiva possível 
(C02\#5). Sempre que o enquadramento for subjetivo, teremos, nos termos de Kress e van Leeuwen (2006), heteroglossia - várias possibilidades de significados. Nesse corpus, como Economou (2009), encontramos que para o engajamento heteroglóssico visual, diferentemente da linguagem verbal, não há contração dialógica, apenas expansão. Assim, imagens como T13\#1, S13\#2, A13\#3 e S12\#4 apresentam uma atitude autoral subjetiva, que revela o engajamento do fotógrafo ou do responsável pela recontextualização da foto.

Quanto à gradação em imagens, observamos que o foco e a força são dois subsistemas responsáveis por desencadear, principalmente, avaliações implícitas, como nas imagens T13\#1 e S13\#2. A gradação visual associa-se diretamente à maneira como os elementos visuais são representados para o leitor e, de acordo com nossa investigação, é o elemento que desencadeia e, muitas vezes, possibilita as demais posições avaliativas por parte do leitor.

\section{Considerações Finais}

O Sistema de Avaliatividade Visual para imagens jornalísticas depende de no mínimo três elementos: i) participante interativo (leitor); ii) participante executor (fotógrafo/diagramador); e iii) participante representado. É, portanto, da mesma forma que no modo semiótico verbal, um sistema principalmente ligado à metafunção interpessoal, mas expresso não somente por ela.

Em imagens, os "gatilhos" avaliativos perpassam as diferentes metafunções de maneira mais saliente do que em relação ao modo semiótico verbal e se expressam na maioria das vezes concomitantemente, podendo apresentar variações conforme o conhecimento compartilhado entre leitor e executor da imagem, o conhecimento do contexto e o posicionamento ideológico de cada um. Em síntese, de acordo com nossa investigação, em imagens jornalísticas, as marcas avaliativas atitudinais de afeto são as mais explícitas e se realizam pela expressão facial e corporal dos participantes representados. O julgamento pode ser explícito, quando ideacionalmente representado, ou implícito, quando atribuído pelo leitor. A apreciação está 
diretamente ligada ao julgamento, podendo ser explícita ou atribuída pelo leitor aos comportamentos, objetos e elementos corporais representados, bem como, à imagem como artefato.

O engajamento visual relaciona-se diretamente à atitude objetiva ou subjetiva conferida pelo enquadramento da foto. Assim, a monoglossia se revela pela atitude autoral objetiva e a heteroglossia pela atitude autoral subjetiva. Em imagens, não há contração dialógica, apenas expansão.

A gradação é sempre explícita e pode ocorrer textualmente (foco) ou espacialmente (força). Segundo nossa pesquisa, esse subsistema é, em imagens, o ponto de entrada para a avaliação visual. Por meio da gradação, a atitude e o engajamento implícito e explícito podem ser apreendidos pelo leitor ou dados a ver pelo fotógrafo ou diagramador.

Este estudo demonstrou ser possível identificar, sistematizar, categorizar e investigar os efeitos de marcas avaliativas em imagens. Além disso, entendemos que este estudo contribui para a área da análise do discurso sistêmico-funcional, oferecendo categorias para a investigação das marcas textuais do contexto (crenças, valores, ideologias) de efetivação do texto e da prática discursiva à qual ele está vinculado (campo, relação e modo), ao que parece, especialmente expressas pela avaliatividade. Destacamos, contudo, que para que se proponha um Sistema de Avaliatividade Visual é necessário o desenvolvimento de uma investigação mais abrangente, enfocando imagens de outros campos de conhecimento como o científico, outros códigos imagéticos como o tecnológico, sempre levando em consideração as questões relativas ao contexto de execução e recontextualização das imagens.

Entendemos, também, que este estudo abre espaço para o desenvolvimento de estudos futuros, por exemplo, em torno da análise de gêneros multimodais (que mobilizam mais de um modo semiótico), possibilitando investigar e comparar os diferentes níveis de realização das linguagens (visual e verbal, p. ex.), levando em consideração o papel da avaliatividade para a efetivação dos significados de tais textos. Além disso, este 
estudo pode auxiliar estudos futuros com interesse na compilação de ferramentas didáticas que propiciem maior entendimento do modo semiótico visual, instigando os leitores a serem mais atentos e críticos aos rastros avaliativos subjacentes às imagens em geral.

\section{Referências}

ALVES, L. A inconsolável dor da perda. 2015. Disponível em: <http://www.premioliberobadaro.com.br/site/noticias.asp>. Acesso em: jun. 2016.

BATEMAN, John, A. Multimodality and genre: a foundation for the systematic analysis of multimodal documents. London: Palgrave Macmillan, 2008.

BERNSTEIN, Basil. Poder, educación y conciencia: sociologia de la transmisión cultural. Santiago: Cide, 1988.

COPE, Bil; KALANTZIS, Mary. Multiliteracies: literacy learning and the design of social futures. London: Routledge, 2000.

CORREDO, Wânia. Execução em uma rua do Benfica. 2015. Disponível em: <http://obutecodanet.ig.com.br/index.php/2011/08/16/fotos-brasileiras-e-suashistorias-premiadas-pelo-premio-esso-de-1991-a-2010/>. Acesso em: jun. 2016.

DOMINGOS, João. Desconfiado de Dilma, PMDB faz plano para 2014. O Estado de São Paulo, São Paulo, 20 ago. 2011. Disponível em:

<http://blogs.estadao.com.br/radar-politico/2011/08/23/estadao-desmentefoto-montada>. Acesso em: 5 mar. 2017.

ECONOMOU, Dorothy. Photos in the news: appraisal analysis of visual semiosis and visual-verbal intersemiosis. 2009. Thesis (PhD doctoral), University of Sydney, Sydney, 2009.

O GOVERNO de SP diz que será mais duro contra vandalismo. Folha de São Paulo, São Paulo, 13 jun. 2013. Cotidiano 1C2.

HALLIDAY, Michael Alexander Kirkwood. An introduction to functional grammar. London: Edward Arnold, 1994

HALLIDAY, Michael Alexander Kirkwood; HASAN, Ruqaiya. Language, context, and text: aspects of language in a social-semiotic perspective. Oxford: Oxford University Press, 1985. 
HALLIDAY, Michael Alexander Kirkwood; MATTHIESSEN, Christian M. I. M. An introduction to functional grammar. 3. ed. London: Hodder Arnold, 2004.

HALLIDAY, Michael Alexander Kirkwood; MATTHIESSEN, Christian M. I. M. Halliday's introduction to functional grammar. 4. ed. London: Routledge, 2014.

HENDGES, Graciela Rabuske; NASCIMENTO, Roséli Gonçalves; MARQUES, Pâmela Marques. A gramática da imagem como ferramenta na análise crítica de gêneros midiáticos. In: SEIXAS, L.; PINHEIRO, N. F. (Org.). Gêneros: um diálogo entre comunicação e Linguística Aplicada. Florianópolis: Insular, 2013. p. 241-274.

KRESS, Gunther R. 2003. Literacy in the new media age. London: Routledge, 2003.

KRESS, Gunther R.; VAN LEEUWEN, Theo. Colour as a semiotic mode: notes for a grammar of colour. Visual Communication, Thousand Oaks, v. 1, n. 3, p. 343368, 2002.

KRESS, Gunther R.; VAN LEEUWEN, Theo. Front pages: (the critical) analysis of newspaper layout. In: BELL, A.; GARRETT, P. (Ed.). Approaches to media discourse. Oxford : Blackwell, 1998. p. 186-219.

KRESS, Gunther R.; VAN LEEUWEN, Theo. Reading images. Geelong: Deakin University Press, 1990.

KRESS, Gunther R.; VAN LEEUWEN, Theo. Reading images: the grammar of visual design. London and New York: Routledge, 1996.

KRESS, Gunther R.; VAN LEEUWEN, Theo. Multimodal discourse: the modes and media of contemporary communication. London: Routledge, 2001.

KRESS, Gunther R.; VAN LEEUWEN, Theo. Reading images: the grammar of the design visual. London: Routledge, 2006.

LANKSHEAR, Colin; KNOBEL, Michele. New literacies changing knowledge and classroom learning. Buckingham: Open University Press, 2003.

LEAL, Luciana Nunes. Índios adotaram estratégias diferentes. O Estado de São Paulo, 24 jun. 2012. Planeta, p. H6.

LEMKE, Jay. Multiplying meaning: visual and verbal semiotics in scientific text. In: MARTIN, J. R.; VEEL, R. (Ed.). Reading sience. London: Routledge, 1998. p. 87-113. 
LIMA, Sóstenes; COROA, Maria Luiza M. S. Configuração e papel do sistema de avaliatividade no gênero reportagem. Calidoscópio, São Leopoldo, v. 8, n. 2, p. 127-137, 2010.

MARTIN, Jim. Fair trade: negociation meaning in multimodal texts. In: COPPOCK, P. (Ed). The semiotics of writing: transdisciplinary perspectives on the technology of writing. Belgium: Brepols/Turnhout, 2001. p. 311-338.

MARTIN, Jim R.; WHITE, P. R. R. The language of evaluation: appraisal in English. London: Continuum, 2005.

MARTINEC, Radan. Nascent and mature uses of a semiotic system: the case of image-text relations. Visual communication, Thousand Oaks, v. 12, n. 2, p. 147-172, 2013.

MARTINEC, Radan; SALWAY, Andrew. A system for image-text relations in new (and old) media. Visual communication, Thousand Oaks, v. 4, n. 3, p. 339-374, 2005.

NININ, Maria Otilia Guimarães; BARBARA, Leila. Engajamento na perspectiva linguística sistêmico-funcional em trabalhos de conclusão de curso de Letras. Trabalhos em Linguística Aplicada, Campinas, v. 52, n. 1, p.127-146, 2013.

O BUTECO DA NET. Fotos brasileiras (e suas histórias) premiadas pelo 'Prêmio Esso' de 1991 à 2010. ago. 2011. Disponivel em:

$<$ http://obutecodanet.ig.com.br/index.php/2011/08/16/fotos-brasileiras-e-suashistorias-premiadas-pe lo-premio-esso-de-1991-a-2010/>. Acesso em: 12 abr. 2017.

O'HALLORAN, Kay L. Towards a systemic functional analysis of multisemiotic mathematics texts. Semiótica, Berlin, v. 124, n. 1/2, p. 1-29, 1999.

O'TOOLE, Michael. The language of displayed art. Leicester: Leicester University Press, 1994.

ROYCE, Terry D. Synergy on the page: exploring inter-semiotic complementarity in page-based multimodal text. JASFL Occasional Papers, Sendai, v. 1, n. 1, p. 25-49, 1998.

ROYCE, Terry D. Multimodality in the TESOL classroom: exploring visual-verbal synergy. TESOL Quarterly, Washington, v. 36, p. 191-205, 2002.

ROYCE, Terry D. Intersemiotic complementarity: a framework for multimodal discourse analysis. In: ROYCE, T. D.; BOWCHER, W. L. New directions in the analysis of multimodal discourse. New Jersey: Lawrence Erlbaun Associates, 2007. 
ROYCE, Terry D. Intersemiotic complementarity in legal cartoons: an ideational multimodal analysis. International journal for the semiotics of law - Revue internationale de sémiotique juridique, Netherlands, v, 28, n. 4, p. 719-744, 2015.

SAUSSURE, Ferdinand de. Curso de Linguística Geral. São Paulo: Cultrix, 1975.

TAVARES, Victor Dragonetti. 580 Prêmio Esso de Fotografia, 2013. Disponível em: <http://www.premioesso.com.br/site/noticias/release_2013_04.aspx>. Acesso em: jun. 2016.

TRUDA, Felipe; MENEZES, Paula. Personagens de cenas marcantes relembram tragédia na boate Kiss. Globo.com, G1, 27 jan. 2015. Disponível em: <http://g1.globo.com/rs/rio-grande-do-sul/noticia/2015/01/personagens-decenas-marcantes-relembram-tragedia-na-boate-kiss.html>. Acesso em: 3 jun. 2017.

VAN LEEUWEN, Theo. Speech, music, sound. London: Macmillan, 1999.

VIAN JR., Orlando. O Sistema de Avaliatividade e os recursos para gradação em língua portuguesa: questões terminológicas e de instanciação. DELTA: documentação de estudos em lingüística teórica e aplicada, São Paulo, v. 25, n. 1, p. 99-129, 2009.

WHITE, Peter. Engagement: notes and miscellaneous.. INTERNATIONAL SYSTEMIC-FUNCTIONAL CONGRESS, 38., Lisbon, 2011. Workshop on Engagement ... Lisbon: University of Lisbon, 2011.

WILTON, Silva JR. Touché. 2015. Disponível em:

<http://www.premioesso.com.br/site/noticias/release_2012_03.aspx>. Acesso em: jun. 2016.

WILTON, Silva JR. $30^{\circ}$ Prêmio Rei da Espanha de Jornalismo, 2013. Disponível em: <http://www.efe.com/premios/rey/principal.asp?opcion=9\&seccion=95\&idi oma=ESPANOL $>$ Acesso em: jun. 2015. 